\title{
Surveying decorative lights of garden cafe in Thu Duc district and proposing some new light patterns for the garden cafe
}

\author{
Thao V. Nguyen*, Nam P. Cam, Hang T. Nguyen, Thao N. Le, \\ Tien T. M. Duong, \& Thuy T. Vuong
}

Faculty of Environment and Natural Resources, Nong Lam University, Ho Chi Minh City, Vietnam

\begin{abstract}
ARTICLE INFO
Research Paper

Received: June 12, 2020

Revised: September 09, 2020

Accepted: October 15, 2020

Keywords

Decorative light

Garden coffee shop

Lighting

Thu Duc district

\section{*Corresponding author}

Nguyen Van Quan

ABSTRACT

This study was carried out from September 2018 to May 2019 at some garden cafes in Thu Duc district. The objective of the study was to survey different types of lights used for decoration of cafe gardens. The study used questionnaires of light characteristics for data collection and then the information collected was analyzed and evaluated for creating lighting designs. The district selected for investigation was divided by wards, routes and cafe areas. The results showed that the majority of 40 garden cafes investigated had LEDs with yellow or white color. Due to the space of cafes, drop lights were preferred and light installation was focused on walkways using lights without lampshades. Five lighting models were designed using concentrated lighting with natural images such as bamboo, sunshine, water surface and folk items like bamboo fish trap. Briefly, the findings of this study would contribute to the improvement of decorative lights for existing garEmail: nckh.canhquanhoavien@hcmuaf.edu.vnden cafes in Thu Duc district.
\end{abstract}

Cited as: Nguyen T. V., Cam, N. P., Nguyen, H. T., Le, T. N., Duong, T. T. M., \& Vuong, T. T. (2020). Surveying decorative lights of garden cafe in Thu Duc district and proposing some new light patterns for the garden cafe. The Journal of Agriculture and Development 19(5), 80-97. 


\title{
Khảo sát đèn trang trí quán cà phê sân vườn khu vực quận Thủ Đức và đề xuất một số mẫu đèn mới cho sân vườn quán cà phê
}

\author{
Nguyễn Văn Thao*, Cầm Phương Nam, Nguyễn Thúy Hằng, Lê Ngọc Thảo, \\ Dương Thị Mỹ Tiên \& Vương Thị Thủy
}

Khoa Môi Trường và Tài Nguyên, Trường Đại Học Nông Lâm TP.HCM, TP. Hồ Chí Minh

\section{THÔNG TIN BÀI BÁO}

\section{Bài báo khoa học}

Ngày nhận: 12/06/2020

Ngày chỉnh sửa: 09/09/2020

Ngày chấp nhận: 15/10/2020

\section{Từ khóa}

Chiếu sáng

Đèn trang trí

Quán cà phê sân vườn

Quận Thủ Đức

*Tác giả liên hệ

Nguyễn Văn Thao

Email: nckh.canhquanhoavien@hcmuaf.edu.vn

\section{TÓM TẮT}

Nghiên cứu được thực hiện từ tháng 9/2018 đến tháng 5/2019 tại 40 quán cà phê sân vườn ở quận Thủ Đức. Mục tiêu của nghiên cứu nhằm khảo sát các loại đèn dùng trong trang trí sân vườn của quán cà phê. Nghiên cứu đã sử dụng bảng câu hỏi khảo sát các đặc tính của đèn và sau đó thông tin thu thập được phân tích và đánh giá để tạo ra các thiết kế chiếu sáng. Nhóm tác giả phân địa điểm khảo sát theo khu vực từng phường, theo các tuyến đường để điều tra và theo khu vực làng cà phê. Kết quả đã khảo sát được 40 quán cà phê, đa phần các quán cà phê sử dụng đèn Led, màu sắc đèn của ánh sáng đèn chủ yếu là vàng và trắng. Do đặc thù không gian nên đèn thả được ưu tiên hơn, đèn lắp chủ yếu ở lối đi và đèn không sử dụng chao đèn. Chúng tôi cũng thiết kế mới 5 mẫu đèn, áp dụng phương pháp chiếu sáng tập trung và nổi bật với cảm hứng thiết kế từ hình ảnh của thiên nhiên như lũy tre, nắng sớm, mặt nước và các vật dụng dân gian như nơm bắt cá. Tóm lại, kết quả nghiên cứu đóng góp vào việc cải tiến đèn trang trí cho các quán cà phê sân vườn hiện có ở quận Thủ Đức.

\section{1. Đặt Vấn Đề}

Từ thế kỷ XIX, người Pháp đã mang cà phê đến Việt Nam. Trải qua nhiều thăng trầm lịch sử, cà phê càng có chỗ đứng vững chắc trong đời sống của người Việt, nó không chỉ là thức uống mà còn là cách sống (Nguyen, 2019). Khi bước vào quán cà phê, ấn tượng đầu tiên của khách hàng là không gian và ánh sáng, sau đó là đồ uống và phục vụ. Ấn tượng về thị giác ảnh hưởng đến tâm thái, khẩu vị của khách hàng và ánh sáng đóng vai trò chủ chốt trong việc gây ấn tượng thị giác (Blight, 2019).

Duijnhoven \& ctv. (2018) cho rằng, ánh sáng có khả năng cải thiện diện mạo của môi trường đô thị và tăng sức hấp dẫn của thành phố. Hệ thống

chiếu sáng được thiết kế tốt có thể cải thiện chất lượng cuộc sống và tránh ô nhiễm ánh sáng. Lợi ích của chiếu sáng được xem xét ở mức độ cá nhân và xã hội như đảm bảo việc an toàn trong di chuyển, nhận thức về an ninh của khu vực và bảo vệ tài sản cá nhân; lợi ích xã hội có thể mở rộng sang nền kinh tế và chất lượng cuộc sông của người dân (Boyce, 2019).

Theo Juchem \& ctv. (2018), mức độ ánh sáng là một yếu tố quan trọng ảnh hưởng đến tâm trạng con người, ánh sáng kém hoặc chiếu sáng cực mạnh làm tăng mức độ căng thẳng. Sức khỏe con người có thể bị ảnh hưởng, hỗ trợ và kiểm soát thông qua việc kiểm soát ánh sáng (Duijnhoven \& ctv., 2018). Phản ứng sinh lý của con người đáp trả lại các đặc tính của ánh sáng như màu sắc, 
cường độ, thời gian và không gian chiếu sáng của ánh sáng. Giải pháp về chiếu sáng có thể giúp tăng cường hoạt động và cải thiện tâm trạng. Theo Alison \& Aparna (2014), lượng ánh sáng quá nhiều sẽ tác động đến phản ứng cũng như chi phối cảm xúc con người. Do đó, với cường độ ánh sáng vừa phải, dịu nhẹ sẽ giúp những quyết định được đưa ra hợp lý hơn, giải quyết các cuộc đàm phán dễ dàng hơn. Sự chói sáng ảnh hưởng đến khả năng làm việc của mắt như sau: góc mắt - đèn $40^{\circ}$ làm giảm $42 \%$ khả năng làm việc của thị giác; góc mắt - đèn $20^{\circ}$ làm giảm $53 \%$; góc mắt - đèn $20^{\circ}$ - giảm $69 \%$; còn nếu góc mắt - đèn $10^{\circ}$ - giảm 84\%" (Luckiesh \& Moss, 1986, dẫn theo Tran \& ctv., 2017). Điều này chi phối việc tổ chức không gian thư giãn cho con người, giúp mắt tránh việc điều tiết quá nhiều, qua đó giúp tâm trạng người nhẹ nhàng, thoải mái hơn.

Chiếu sáng nghệ thuật trong kiến trúc là việc khai thác hiệu quả ánh sáng nhân tạo để làm nổi bật các đặc điểm kiến trúc đặc trưng của công trình nhằm tạo ra sự sống động, rực rỡ hơn cho công trình vào ban đêm. Hiệu quả của việc chiếu sáng đạt được thông qua phương pháp bố trí chiếu sáng, mức độ chiếu sáng và màu sắc ánh sáng. Ánh sáng với màu sắc của nó không những thu hút, tạo sự bắt mắt mà còn phản ánh được cái hồn của đối tượng được chiếu sáng (Nguyen, 2019). Màu sắc ánh sáng cũng ảnh hưởng trực tiếp đến việc cảm thụ cảnh quan của con người rất rõ ràng, đối với nguồn sáng nóng cam - vàng gây tâm lý phấn khích, tạo cảm giác vui tươi, hưng phấn. Nguồn sáng trung tính trắng ấm tạo cảm giác an toàn, kích thích mắt làm việc, thu hút tầm nhìn. Nguồn sáng lạnh xanh da trời tím tạo cảm giác tươi mát, bình yên, làm dịu đi sự kích thích, màu tím cho cảm giác buồn, uể oải. Theo Bedrosian (2011), ánh sáng ban đêm khiến não bộ điều chỉnh để nhận tín hiệu như lúc ban ngày một cách, điều này không cần thiết và có thể liên quan đến bệnh trầm cảm ở một số người. Do đó, thắp sáng ban đêm nên dùng màu cam đỏ hơn là màu trắng (dẫn theo Nhung, 2015).

Phương pháp chiếu sáng gồm bố trí ánh sáng tổng thể, bố trí ánh sáng tập trung, bố trí ánh sáng trọng tâm. Chiếu sáng trang trí có thể chia thành 10 kiểu (Hình 1): Chiếu sáng lối đi (path lighting), chiếu lên (up lighting), chiếu xuống (down lighting), chiếu sáng rọi bóng (silhouetting), chiếu dọc (gazing light), chiếu tạo bóng (shadowing), chiếu điểm nhấn (accent lighting), chiếu sáng bậc thang/bước đi (step lighting), chiếu sáng an toàn (security lighting) và chiếu sáng chéo (cross lighting) (LDA, 2013).

Mặc dù mục đích chính của thiết bị chiếu sáng là cung cấp ánh sáng, nhưng các kiểu dáng đèn cũng ảnh hưởng rất nhiều đến thẩm mỹ công trình khi không chiếu sáng (Beccali \& ctv., 2018). Theo Harris (1998), việc lựa chọn đèn liên quan đến sự thay đổi về kích thước đèn, hiệu quả ánh sáng, hình dáng, nhiệt độ màu, biểu hiện màu, tuổi thọ đèn, chi phí và bảo trì.

Với mục tiêu tìm hiểu việc sử dụng đèn trang trí, chiếu sáng của quán cà phê sân vườn, đề tài đã điều tra, khảo sát ở một số quán cà phê sân vườn tại quận Thủ Đức, TP. Hồ Chí Minh và đề xuất ý tưởng thiết kế 5 mẫu đèn mới có thể áp dụng cho các quán cà phê tại đây.

\section{Vật Liệu và Phương Pháp Nghiên Cứu}

Phương pháp khảo sát thực địa: mỗi đèn được ghi nhận trực tiếp vào từng phiếu khảo sát. Phiếu khảo sát gồm 3 phần: Mở đầu - thông tin quán cà phê; Phần thông tin chính yếu về các loại đèn; Phần kết thúc - thông tin phụ trợ.

Chọn mẫu theo phương pháp phân tầng. Cỡ mẫu là 40 quán cà phê. Chọn mẫu theo 3 bước: Sử dụng bản đồ số của quận Thủ Đức kết hợp với thông tin về các làng cà phê hiện có để phân vùng các quán cà phê theo từng phường. Thực hiện một đợt khảo sát sơ bộ để kiểm tra lại vị trí quán cà phê, thống kê số quán cà phê và ước lượng diện tích từng quán cà phê tại mỗi phường, khảo sát thử với phiếu khảo sát để điều chỉnh các tiêu chí cho phù hợp nhằm thu thập đầy đủ và đúng thông tin cần nghiên cứu. Phân tích và so sánh về diện tích sân vườn, việc sử dụng đa dạng các loại đèn, hiệu ứng cảnh quan đẹp, bắt mắt, lưu lượng khách đông, phong phú về thành phần, lứa tuổi để tiến hành chọn 40 quán khảo sát chính thức.

Sử dụng phương pháp quan sát để thu thập dữ liệu về kiểu dáng, các loại đèn, cách bố trí, màu sắc, cách phối kết đèn và cây xanh, vật dụng, hình ảnh trước và sau khi đèn trang trí được bật. Chụp ảnh và ghi chú số hiệu ảnh, sau đó mã hóa số hiệu ảnh trong phiếu điều tra để thuận tiện trong việc đánh giá.

Sử dụng phương pháp phỏng vấn để ghi nhận các thông tin phụ trợ về đèn trang trí bằng cách đặt câu hỏi mở với đáp viên, đáp viên gồm có chủ quán, nhân viên quán cà phê và khách uống cà phê. 


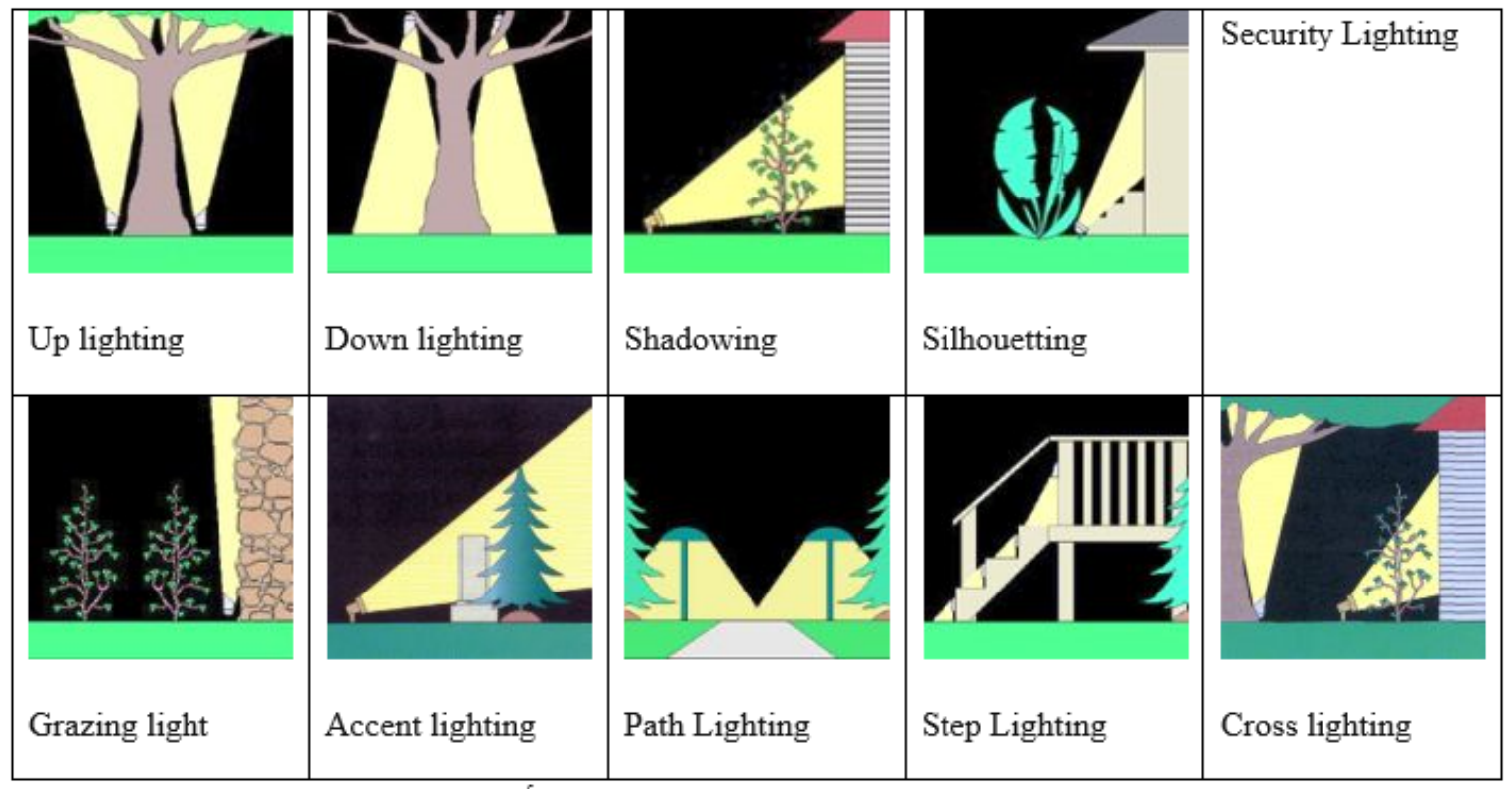

Hình 1. Các phương pháp chiếu sáng.

Tra cứu thông tin đèn gồm dữ liệu về các thông số kỹ thuật của đèn như màu sắc, độ chói sáng, công suất, vật liệu cấu tạo và một số thông tin khác mà nhà sản xuất đã khuyến nghị cho việc sử dụng đèn.

Dư liệu sau khi thu thập được tổng hợp trên phần mềm Microsoft Excel để phân tích, vẽ biểu đồ và thống kê. Sử dụng các phần mềm thiết kế như AutoCAD, Sketchup, Lumion và Photoshop để thiết kế mẫu đèn.

\section{Kết Quả và Thảo Luận}

\subsection{Số lượng quán cà phê sân vườn}

Đề tài đã khảo sát được 40 quán cà phê sân vườn, trong đó, phường Bình Thọ có 16 quán (tỷ lệ 40\%), phường Hiệp Bình Chánh có 10 quán (tỷ lệ 25\%), phường Linh Chiểu có 4 quán (10\%), ở phường Tam Phú có 3 quán $(7,5 \%)$, phường Hiệp Bình Phước và Linh Trung có 2 quán mỗi phường (tổng cộng 10\%), các phường Tam Bình, Bình Chiểu và Trường Thọ có 1 quán (tổng cộng $7,5 \%$ ). Đa số các quán ở phường Bình Thọ (Hình 2) vì đây là khu vực làng cà phê nổi tiếng của quận, kế tiếp là phường Hiệp Bình Chánh, các quán ở tuyến đường lớn là đường Phạm Văn Đồng và khu vực ven sông Sài Gòn nhờ có cảnh quan sông đẹp và không khí mát mẻ.

\subsection{Các loại bóng đèn}

Đề tài đã khảo sát được 369 đèn (Bảng 1), nhìn chung, các quán cà phê ưa chuộng sử dụng đèn Led $(77,5 \%)$, kế đến là đèn Compact $(20,9 \%)$ và cuối cùng là đèn dây tóc $(1,6 \%)$. Đèn Led chiếm đa số vì hiệu quả tiết kiệm điện năng, có ánh sáng rõ, sắc nét, ổn định, nhiều màu sắc, mẫu mã, kích cỡ và đa dạng mức giá nên chủ quán cà phê dễ lựa chọn. 9/16 quán ở phường Bình Thọ, 5/11 quán ở phường Hiệp Bình Chánh chỉ sử dụng bóng đèn Led cho cả quán. Các quán còn lại lựa chọn kết hợp đèn Led với 2 loại bóng đèn Compact và dây tóc để khắc phục nhược điểm giá thành cao của đèn.

Đèn Compact được một số quán dùng trang trí chính như Windy (phường Bình Thọ), Mộc (phường Hiệp Bình Chánh), Tí Tách (phường Linh Chiểu), NTS (phường Tam Phú), The Patio (phường Trường Thọ). Đèn được chọn vì ưu điểm tiết kiệm điện năng, ánh sáng rõ, sắc nét, tuổi thọ bền, màu sắc phong phú, nhiều mẫu mã để trang trí, giá thành không cao. Tuy nhiên, ánh sáng của đèn Compact không ổn định trong thời gian dài do tính chất cấu tạo của đèn.

Đèn dây tóc chỉ xuất hiện ở một số quán như Amy (phường Bình Thọ), Opal, Black, Caro (phường Hiệp Bình Chánh), Hoa Giấy (phường Linh Chiểu) do tiêu thụ điện năng cao, tuổi thọ 


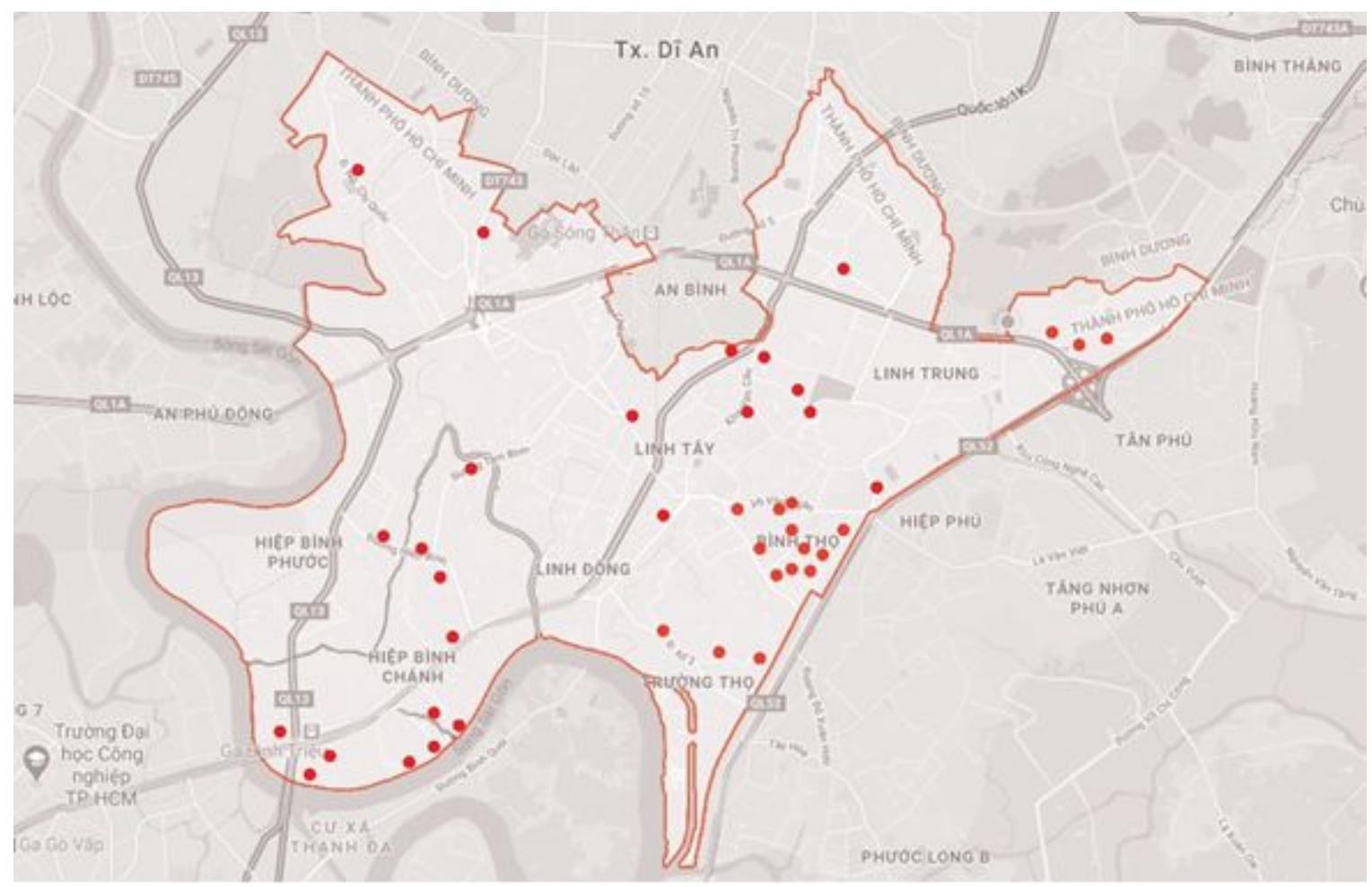

Hình 2. Bản đồ vị trí các quán cà phê đã được khảo sát.

thấp và có thể làm không gian nóng hơn mặc dù ánh sáng đèn ổn định và giá thành rẻ (Hình 3).

\subsection{Màu sắc của ánh sáng đèn}

Với chức năng của quán cà phê là tạo cảm giác thoải mái và thư giãn cho thực khách nên không gian quán là yếu tố quan trọng ảnh hưởng đến sự lựa chọn quán cà phê. Để tạo nên không gian có chiều sâu, hài hòa và tinh tế thì màu sắc của nguồn sáng cần được chú trọng.

Theo Hình 4, việc sử dụng nguồn sáng đa sắc không được ưa chuộng (11\%). Các màu vàng, trắng và đơn sắc khác được lựa chọn nhiều hơn. Ánh sáng màu vàng ấm áp tạo cảm giác thư giãn và giúp ngon miệng được xuất hiện nhiều nhất (41,4\%). Ánh sáng màu trắng giúp dẫn lối, tạo độ sáng và an toàn chiếm tỷ lệ thứ hai $(35,2 \%)$, đây cũng là sự lựa chọn màu dễ phối hợp với các chi tiết trang trí có màu sắc và hình dạng khác nhau. Các màu ánh sáng đơn sắc khác (xanh lục, xanh lam, đỏ) chủ yếu trang trí ở điểm nhấn như bảng hiệu và các tiểu cảnh.

\section{Các loại bóng đèn}

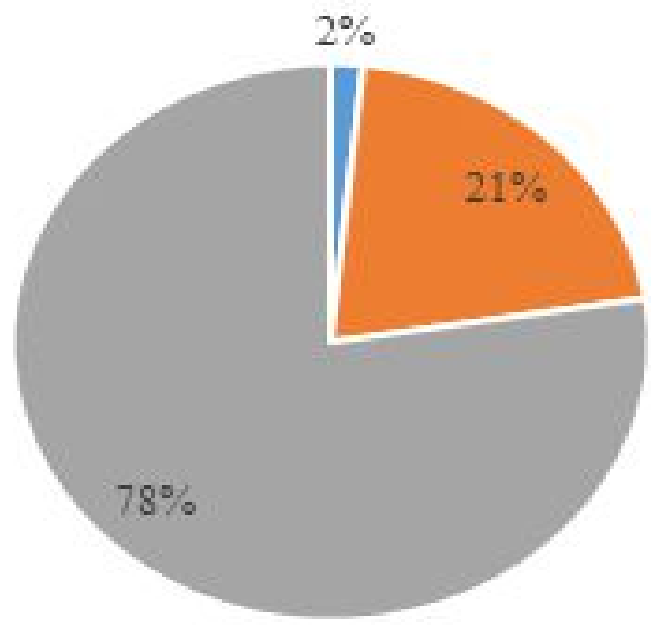

- Dây tóc = Compact = Led

Hình 3. Biểu đồ tỷ lệ các loại bóng đèn. 
Bảng 1. Bảng tổng hợp một số thông tin đèn trang trí quán cà phê

\begin{tabular}{|c|c|c|c|c|c|c|c|c|c|}
\hline $\begin{array}{l}\text { Loại bóng } \\
\text { đèn }\end{array}$ & Led & Compact & $\begin{array}{l}\text { Dây } \\
\text { tóc }\end{array}$ & $\begin{array}{l}\text { Tổng } \\
\text { cộng }\end{array}$ & & & & & \\
\hline $\begin{array}{c}\text { Số lượng } \\
\text { (cái) }\end{array}$ & 286 & 77 & 6 & 369 & & & & & \\
\hline Tỷ lệ (\%) & 77,5 & 20,9 & 1,6 & 100 & & & & & \\
\hline $\begin{array}{l}\text { Màu sắc } \\
\text { của ánh } \\
\text { sáng đèn }\end{array}$ & Trắng & Vàng & $\begin{array}{l}\text { Nhiều } \\
\text { màu }\end{array}$ & $\begin{array}{l}\text { Màu } \\
\text { đơn } \\
\text { sách } \\
\text { khác }\end{array}$ & $\begin{array}{l}\text { Tổng } \\
\text { cộng }\end{array}$ & & & & \\
\hline $\begin{array}{c}\text { Số lượng } \\
\text { (cái) }\end{array}$ & 130 & 153 & 40 & 46 & 369 & & & & \\
\hline Tỷ lệ (\%) & 35,2 & 41,4 & 11 & 12,4 & 100 & & & & \\
\hline $\begin{array}{l}\text { Các kiểu } \\
\text { lắp đèn }\end{array}$ & $\begin{array}{l}\text { Đèn } \\
\text { thả }\end{array}$ & $\begin{array}{l}\text { Đèn } \\
\text { rọi }\end{array}$ & $\begin{array}{l}\text { Đèn } \\
\text { pha }\end{array}$ & $\begin{array}{l}\text { Đèn } \\
\text { trụ }\end{array}$ & $\begin{array}{l}\text { Đèn } \\
\text { âm } \\
\text { tường }\end{array}$ & $\begin{array}{l}\text { Đèn } \\
\text { âm } \\
\text { nước }\end{array}$ & $\begin{array}{l}\text { Đèn lắp } \\
\text { âm khác } \\
\text { (gỗ, trần } \\
\text { thạch } \\
\text { cao,..) }\end{array}$ & Khác & $\begin{array}{l}\text { Tổng } \\
\text { cộng }\end{array}$ \\
\hline $\begin{array}{c}\text { Số lượng } \\
\text { (cái) }\end{array}$ & 176 & 41 & 35 & 18 & 26 & 7 & 42 & 24 & 369 \\
\hline Tỷ lệ (\%) & 48 & 11 & 9 & 5 & 7 & 2 & 11 & 7 & 100 \\
\hline $\begin{array}{l}\text { Vị trí lắp } \\
\text { đèn }\end{array}$ & $\begin{array}{l}\text { Dọc } \\
\text { lối đi }\end{array}$ & $\begin{array}{l}\text { Thả } \\
\text { trần }\end{array}$ & $\begin{array}{l}\text { Trên } \\
\text { cây }\end{array}$ & $\begin{array}{l}\text { Treo } \\
\text { tường }\end{array}$ & $\begin{array}{l}\text { Tường, } \\
\text { vách }\end{array}$ & $\begin{array}{l}\text { Dưới } \\
\text { nước }\end{array}$ & $\begin{array}{l}\text { Tổng } \\
\text { cộng }\end{array}$ & & \\
\hline $\begin{array}{c}\text { Số lượng } \\
\text { (cái) }\end{array}$ & 111 & 104 & 77 & 44 & 26 & 7 & 369 & & \\
\hline Tỷ lệ (\%) & 30 & 28 & 21 & 12 & 7 & 2 & 100 & & \\
\hline $\begin{array}{l}\text { Vật liệu } \\
\text { chao đèn }\end{array}$ & $\begin{array}{c}\text { Không } \\
\text { có }\end{array}$ & $\begin{array}{l}\text { Kim } \\
\text { loại }\end{array}$ & $\begin{array}{l}\text { Nhựa } \\
\text { Tre, } \\
\text { gố }\end{array}$ & Vải & $\begin{array}{l}\text { Thủy } \\
\text { tinh }\end{array}$ & Khác & $\begin{array}{l}\text { Tổng } \\
\text { cộng }\end{array}$ & & \\
\hline $\begin{array}{c}\text { Số lượng } \\
\text { (cái) }\end{array}$ & 154 & 67 & 46 & 22 & 17 & 2 & 61 & 369 & \\
\hline Tỷ lệ (\%) & 42 & 18 & 12 & 6 & 5 & 1 & 16 & 100 & \\
\hline $\begin{array}{l}\text { Hình dáng } \\
\text { chao đèn }\end{array}$ & $\begin{array}{l}\text { Chóp } \\
\text { nón }\end{array}$ & $\begin{array}{l}\text { Cầu, } \\
\text { tròn }\end{array}$ & $\begin{array}{l}\text { Hộp } \\
\text { Đèn } \\
\text { lồng }\end{array}$ & $\begin{array}{c}\text { Nôm } \\
\text { Cây } \\
\text { xanh }\end{array}$ & $\begin{array}{l}\text { Không } \\
\text { có } \\
\text { hoặc } \\
\text { không } \\
\text { xác } \\
\text { định } \\
\end{array}$ & $\begin{array}{l}\text { Tổng } \\
\text { cộng }\end{array}$ & & & \\
\hline $\begin{array}{c}\text { Số lượng } \\
\text { (cái) }\end{array}$ & 39 & 17 & 12 & 14 & 7 & 50 & 230 & 369 & \\
\hline Tỷ lệ (\%) & 10,6 & 4,6 & 3,2 & 3,8 & 2 & 13,5 & 62.3 & 100 & \\
\hline $\begin{array}{l}\text { Tương } \\
\text { quan giữa } \\
\text { phụ kiện } \\
\text { và đèn }\end{array}$ & $\begin{array}{l}\text { Nồi } \\
\text { bật } \\
\text { phụ } \\
\text { kiện }\end{array}$ & $\begin{array}{l}\text { Tạo } \\
\text { hiệu } \\
\text { ứng }\end{array}$ & $\begin{array}{l}\text { Không } \\
\text { tương } \\
\text { quan }\end{array}$ & $\begin{array}{l}\text { Tổng } \\
\text { cộng }\end{array}$ & & & & & \\
\hline $\begin{array}{c}\text { Số lượng } \\
\text { (cái) }\end{array}$ & 72 & 19 & 278 & 369 & & & & & \\
\hline Tỷ lệ (\%) & 20 & 5 & 75 & 100 & & & & & \\
\hline
\end{tabular}

Nguồn: tổng hợp kết quả điều tra năm 2019. 


\section{Màu sắc của ánh sáng đèn}

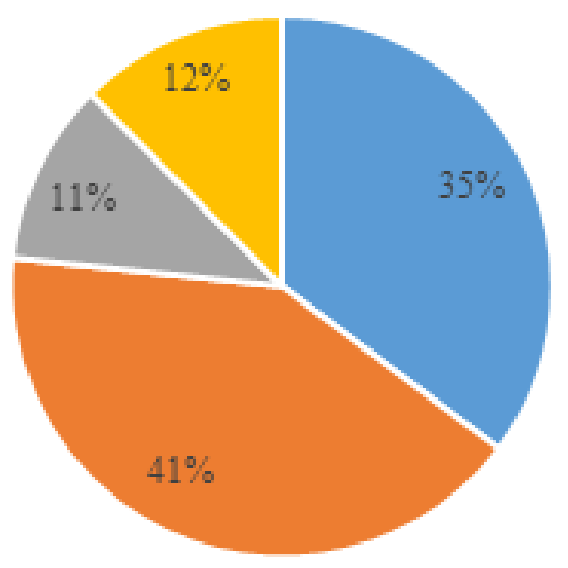

- Trắng "Vàng "Nhiều màu " Đơn sắc khác

Hình 4. Biểu đồ tỷ lệ màu sắc của ánh sáng đèn.

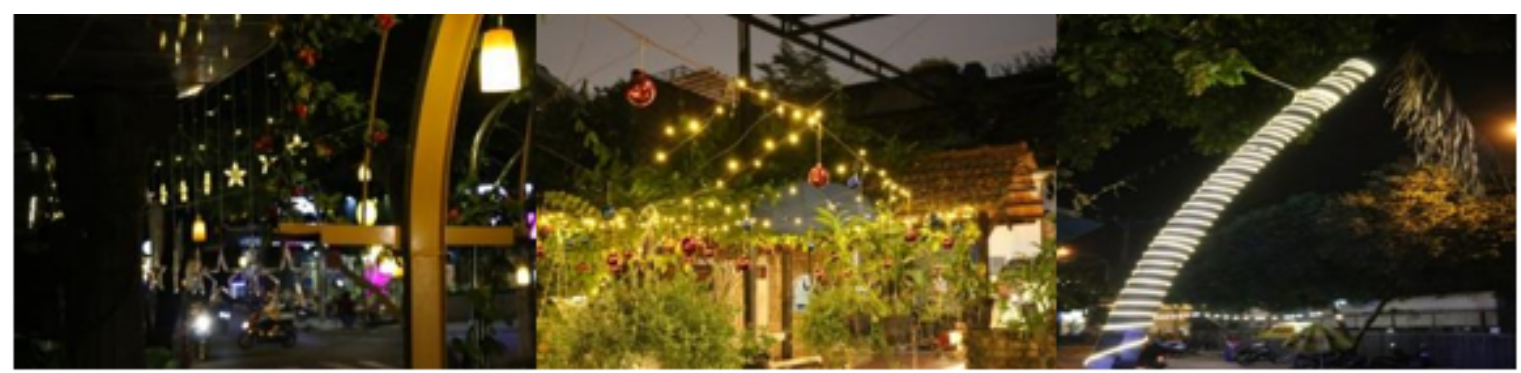

Hình 5. Đèn trang trí tại các quán cà phê Ấn Tượng, Dường Như và Phin.

\subsection{Các kiểu lắp đèn}

Theo Bảng 1, gần 50\% các loại đèn đã khảo sát là đèn thả do đặc thù không gian và diện tích quán ở quận Thủ Đức tương đối nhỏ, giải pháp mở rộng không gian và diện tích theo phương thẳng đứng được ưu tiên hơn. Đèn thả có nhiều mẫu mã đẹp và đa dạng, nguồn sáng được thắp từ trên cao có thể đảm bảo ánh sáng cho thực khách thưởng thức cà phê (Hình 5). Treo đèn thả cũng có thể kết hợp các loại đèn khác, các chao đèn và phụ kiện để trang trí cho quán. Đèn pha và đèn rọi chiếm tỷ lệ $20 \%$, lắp đặt 2 loại đèn này có thể khắc phục nhược điểm diện tích hạn chế và tôn tạo nét đẹp tự nhiên của các loài cây ở quán.
Một số loại đèn cũng được lắp đặt nhưng với tỷ lệ nhỏ (dưới 10\%) như đèn trụ, đèn lắp âm (tường, nước, gỗ, thạch cao). Hạn chế chung của các loại đèn hiện nay là góc chiếu và hướng chiếu đến các vật thể không lột tả được cái đẹp của đường nét, màu sắc và hình dạng vật thể trang trí (vật dụng, phụ kiện, cây xanh và tiểu cảnh).

\subsection{Vị trí lắp đèn}

Vị trí được lắp đèn nhiều nhất là dọc lối đi $(30 \%)$, kế đến là thả trần $(28 \%)$, trên cây $(21 \%)$, treo tường $(12 \%)$, âm tường $(7 \%)$ và cuối cùng là dưới nước ( $2 \%$ ) (Hình 6 ). Đèn được đặt dọc lối đi và thả trần là hai vị trí được ưu tiên nhất, chúng 


\section{Vị trí lắp đặt đèn}

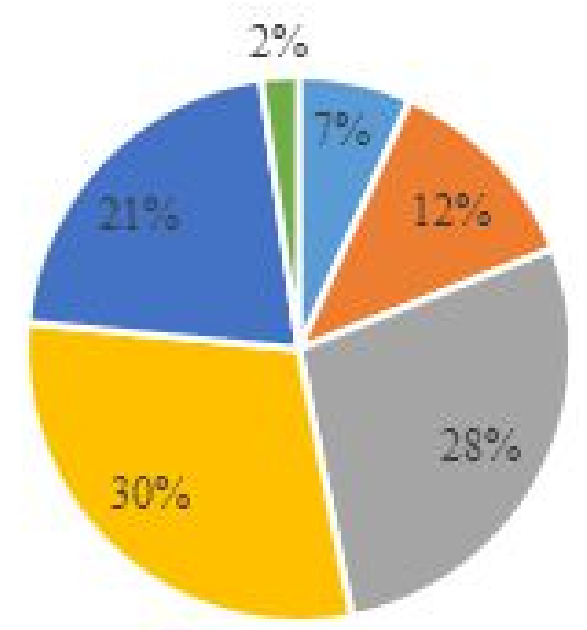

\section{- Âm tường - Treo tường "Thả trần = Dọc lối đi - Trên cây = Dưới nước}

Hình 6. Biểu đồ tỷ lệ các vị trí lắp đặt đèn.

giúp điều hướng và thực hiện chức năng cung cấp ánh sáng chính cho quán.

Các vị trí lắp đèn còn lại được bố trí rải rác ở các tiểu cảnh với chức năng chiếu sáng hoặc nhấn mạnh một ý tưởng trang trí. Tuy nhiên, theo kết quả nghiên cứu, có $70 \%$ các điểm nhấn của quán cà phê chưa được bố trí đèn trang trí hoặc thiết kế chiếu sáng chưa làm nổi bật ý tưởng độc đáo của quán. Các loại đèn được bố trí dàn trải, không mang lại hiệu quả cao về nổi bật không gian, chưa tạo nên nét độc đáo cho quán cà phê.

\subsection{Vật liệu và hình dáng chao đèn}

Đèn không sử dụng chao đèn chiếm tỷ lệ nhiều nhất $(42 \%)$, tiếp đến là chao đèn kim loại $(18 \%)$, nhựa $(12 \%)$, tre gỗ, vải và thủy tinh (từ 1 đến $6 \%$ ) và một số vật liệu khác (Hình 7 ). Chao đèn có hình chóp nón có số lượng 39 cái, hình cầu hoặc có dạng tròn 17 cái, hình hộp 12 cái. Các chao đèn còn lại là phụ kiện đi kèm như đèn lồng (14 cái), cái nôm (7 cái) và kết hợp với cây xanh. Khi đánh giá về tương quan giữa phụ kiện và đèn, chỉ có 5\% (19 cái) tạo được hiệu ứng tốt khi xét đến bóng đổ và ánh sáng đèn kết hợp với vật liệu, màu sắc phụ kiện. Với tiêu chí chỉ nổi bật phụ kiện thì có được 72 đèn $(20 \%)$ có thể làm nổi bật phụ kiện về hình dáng và màu sắc (Bảng 1$)$.

Bóng đổ và màu sắc ánh sáng tạo nên sự khác nhau về thị giác và cảm xúc với mỗi hình dáng đèn khác nhau. Các loại đèn không có chao đèn hoặc chao đèn chưa phong phú về hình dạng, chao đèn chưa kết hợp tốt với đèn nên sự trang trí đèn của các quán cà phê tương tự nhau, dễ "sao chép", không có sự khác biệt và tạo cảm giác nhàm chán cho người đến thưởng thức cà phê.

\section{7. Đèn và phong cách sân vườn quán cà phê}

Thống kê phong cách thiết kế sân vườn 40 quán cà phê thì có 7 quán phong cách vườn Việt Nam, 7 quán vườn nhiệt đới (trong đó, có 2 quán phong cách vườn Singapore), 1 quán phong cách vườn Trung Quốc, 1 quán phong cách vườn Nhật Bản, 1 quán tân cổ điển và 23 quán $(57,5 \%)$ theo phong cách sân vườn kết hợp và xu thế hiện đại. Các quán cà phê sân vườn mang phong cách hiện đại và Việt Nam chiếm tỷ lệ lớn (75\%). Các mẫu đèn có sã̃n, dễ tìm thấy trên thị trường và mang tính chất trung tính có thể bố trí ở nhiều quán cà phê mang phong cách thiết kế khác nhau, vị trí lắp đặt đa dạng chiếm tỷ lệ nhiều nhất (175 đèn, 


\section{Vật liệu chao đèn}

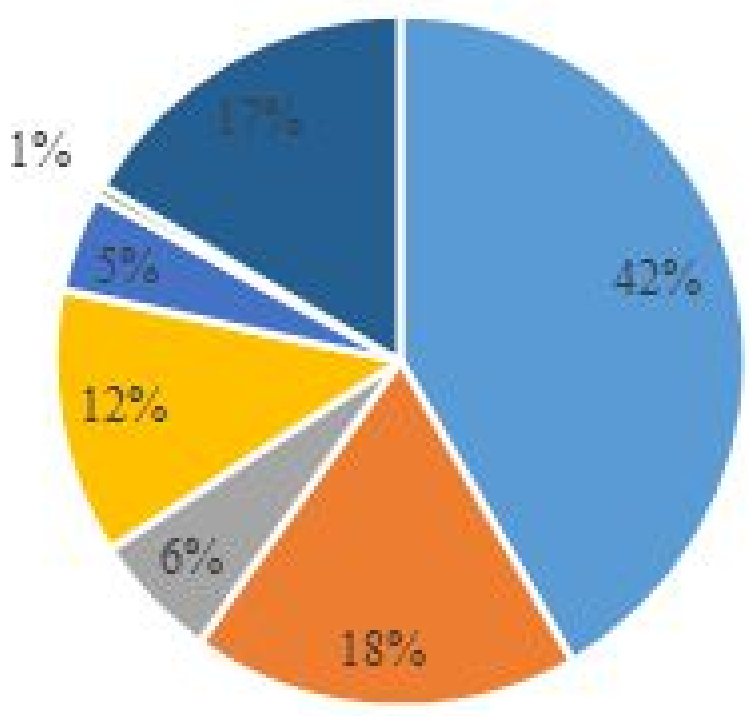

- Không có = Kim loại =Tre, gỗ " Nhựa = Väi = Thủy tinh = Khác

Hình 7. Biểu đồ tỷ lệ vật liệu chao đèn.

chiếm 47\%). Đèn phù hợp phong cách thiết kế sân vườn là (124 đèn, chiếm 34\%), trong khi đó, có 70 đèn $(19 \%)$ chưa phù hợp với phong cách sân vườn của quán cà phê (chủ yếu ở phong cách vườn Việt Nam và vườn nhiệt đới).

Qua khảo sát và phân tích về đèn trang trí quán cà phê sân vườn ở quận Thủ Đức, chúng tôi nhận thấy các quán cà phê sử dụng phương pháp chiếu sáng toàn cảnh cho đa số các loại đèn. Phương pháp chiếu sáng này thay thế và bổ sung cho nguồn sáng tự nhiên, bố trí ánh sáng đều khắp và độ sáng vừa phải. Một số quán cà phê có sử dụng phương pháp chiếu sáng kết hợp với chiếu sáng hướng xuống. Phương pháp chiếu sáng toàn cảnh thường gây nhàm chán vì ít thay đổi hiệu ứng đèn, điểm nhấn về ánh sáng cho không gian quán nói chung và các tiểu cảnh trang trí không rõ ràng. Để khắc phục các hạn chế này, đề tài thiết kế 5 mẫu đèn mới chủ yếu áp dụng chiếu sáng tập trung và chiếu sáng làm nổi bật, nguồn sáng sử dụng đa dạng hơn, vật thể cần được nhấn mạnh sẽ được thể hiện rõ bằng cách chiếu tập trung vào vật thể, tạo hiệu ứng mạnh và gây sự chú ý, làm nổi bật cho ý đồ trang trí và tạo điểm nhấn cho quán.

\subsection{Thiết kế 5 mẫu đèn trang trí sân vườn quán cà phê}

\subsubsection{Mẫu đèn 1}

Cảm hứng thiết kế là hình ảnh nắng sớm chiếu xuyên qua những tán lá của bụi tre (Hình 8). Đèn có cấu tạo gồm 4 phần: Đế đèn hình vuông kích thước $300 \mathrm{~mm} \times 300 \mathrm{~mm}$ được làm bằng kim loại, trang trí cỏ nhân tạo như bụi tre mọc trên mặt đất; Trụ đèn hình trụ, vật liệu tầm vông sơn chống thấm nước và mối mọt. Đèn có 5 trụ được sắp xếp tăng dần từ thấp đến cao tạo hình ảnh cây tre ngày càng phát triển và hiệu ứng $3 \mathrm{D}$ búp măng cho đèn; Sử dụng 5 bóng đèn Led màu trắng, đui đèn E27 giúp tiết kiệm điện; Chao đèn là kính nhựa trong màu vàng nhạt tạo ánh sáng mờ ảo như nắng sớm, các ống kính nhựa được 


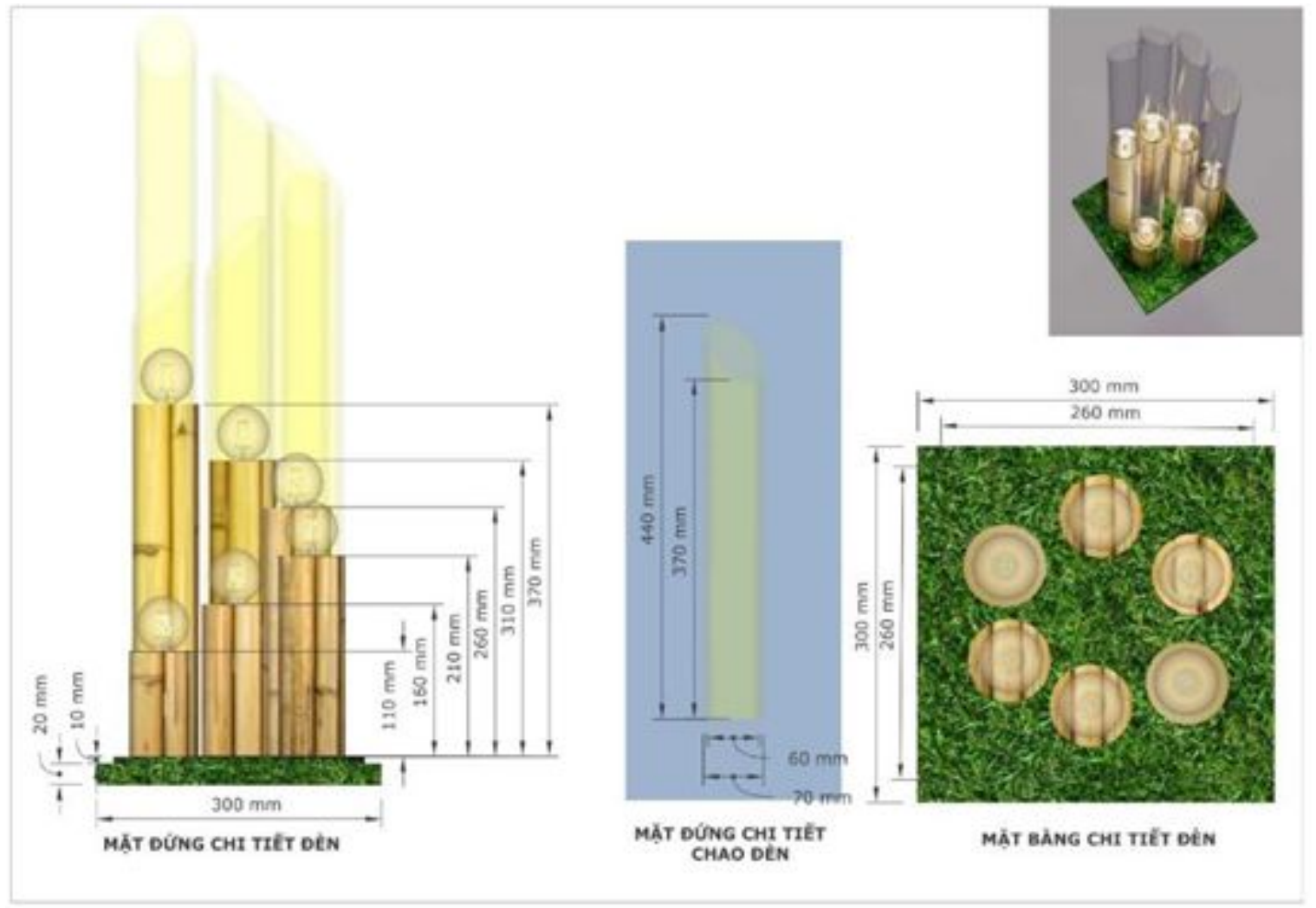

Hình 8. Chi tiết mẫu đèn 1.

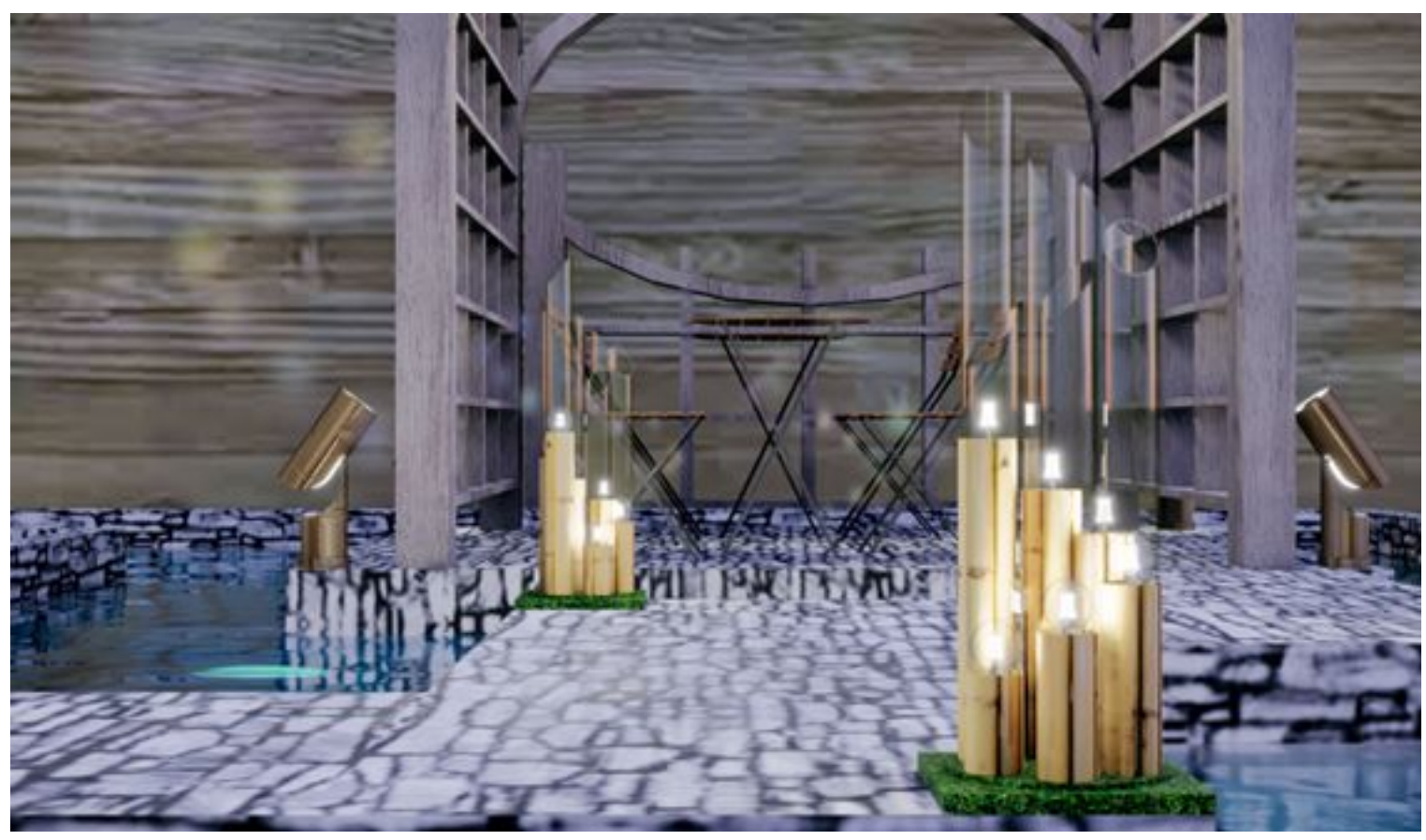

Hình 9. Phối cảnh mô hình mẫu đèn 1. 


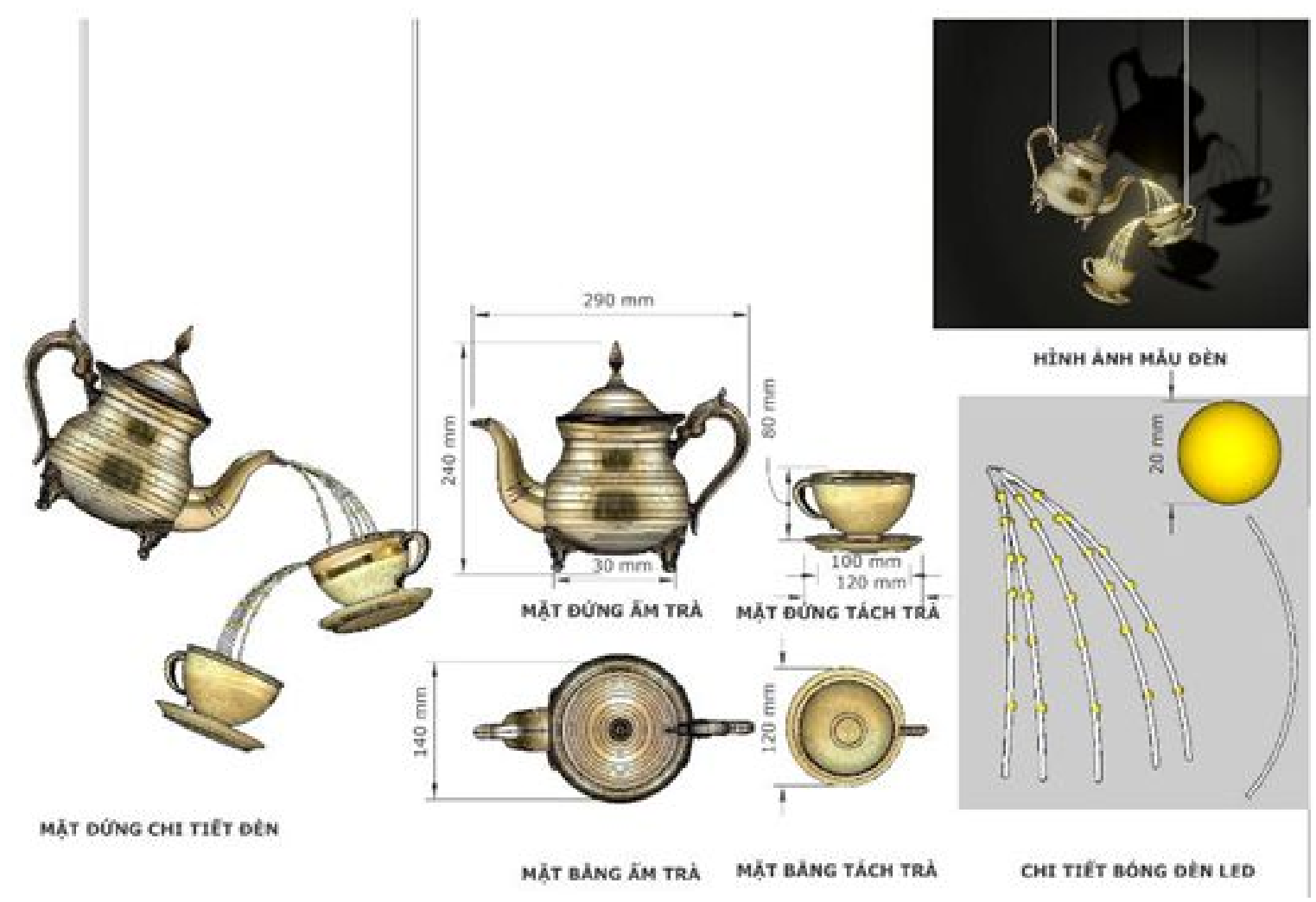

Hình 10. Chi tiết mẫu đèn 2 .

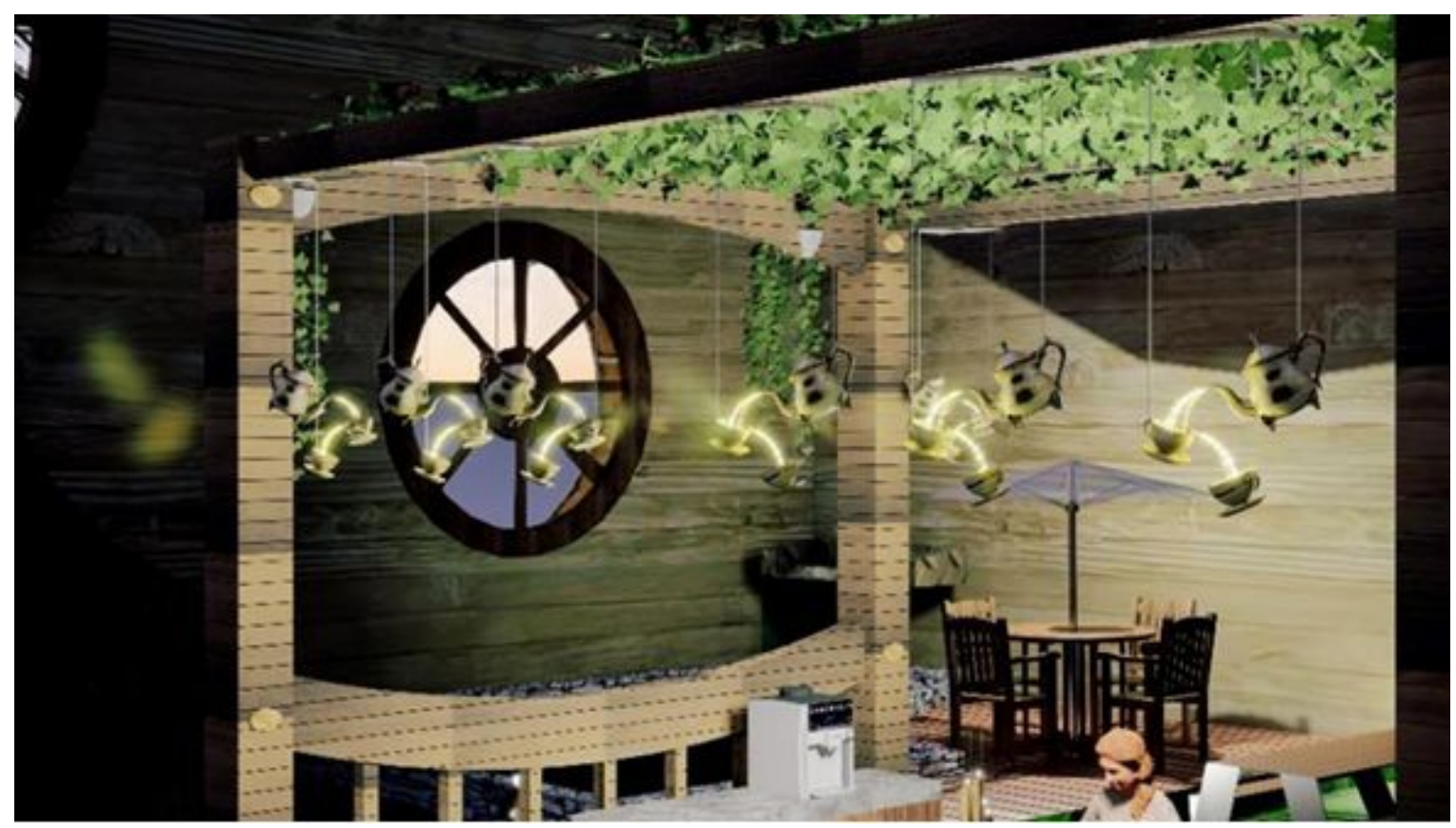

Hình 11. Phối cảnh mẫu đèn 2. 

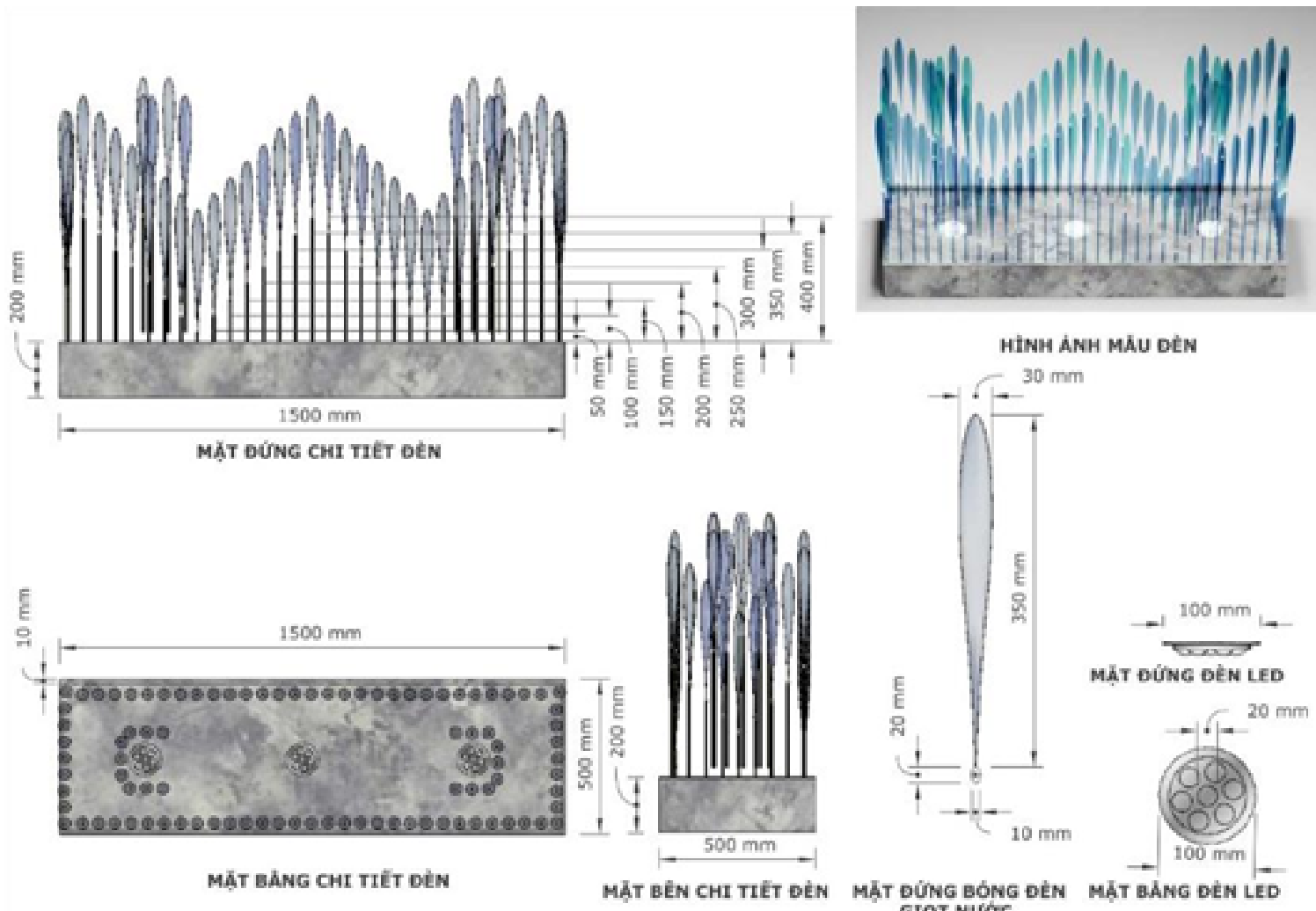

Hình 12. Chi tiết mẫu đèn 3.

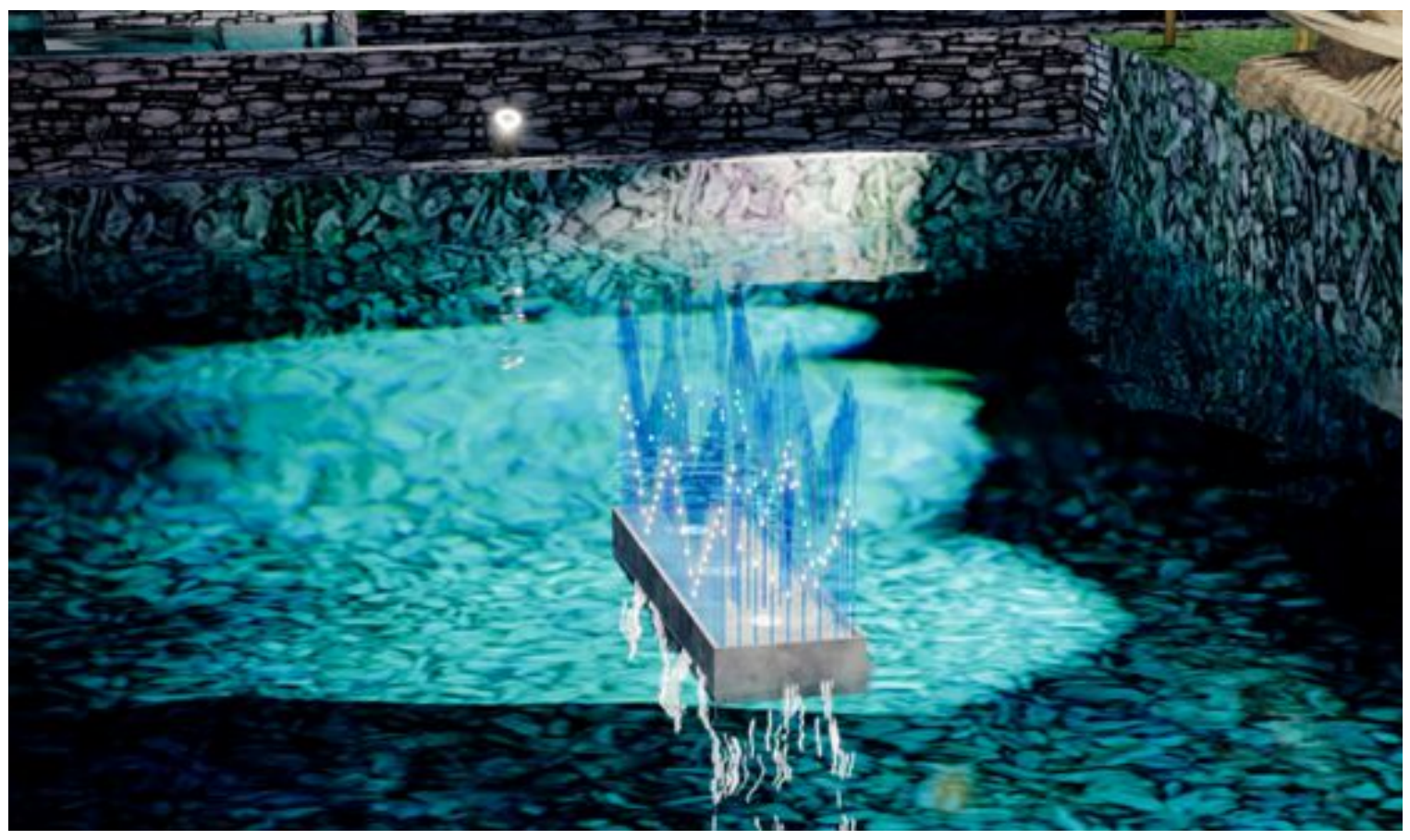

Hình 13. Phối cảnh mẫu đèn 3. 


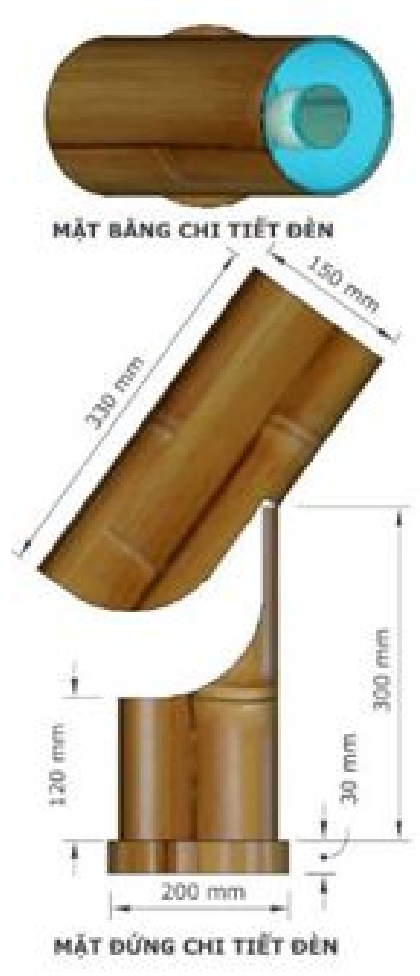

Hình 14. Chi tiết mẫu đèn 4 .

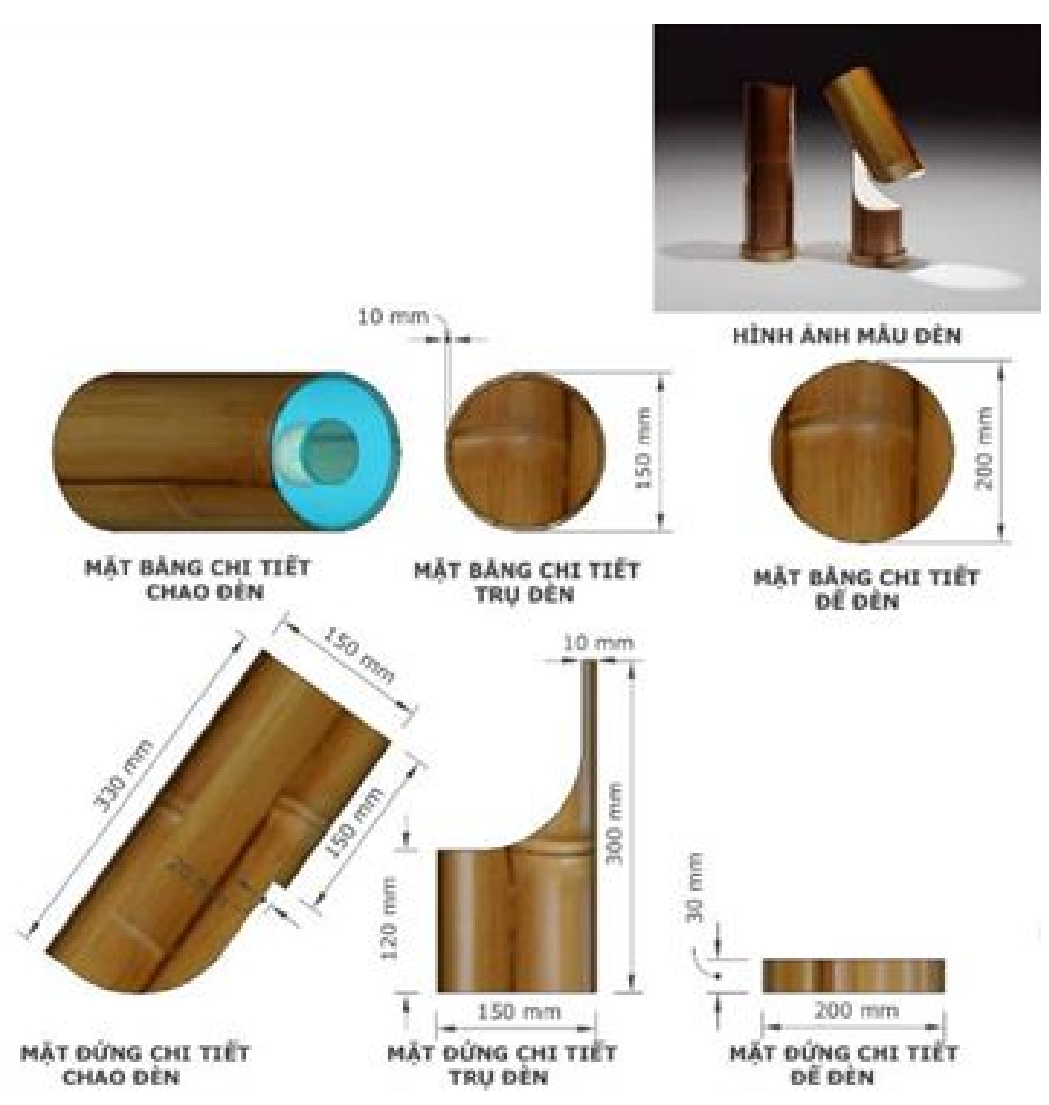

sắp xếp tăng dần theo chiều cao của chao đèn tạo hiệu ứng in bóng đổ khi đèn chiếu sáng.

Với hệ thống 5 bóng đèn Led góc chiếu rộng $270^{\circ}$ hướng chiếu từ dưới lên (up lighting), hướng sự chú ý của người xem vào vật được chiếu sáng hoặc không gian bên trên (Hình 9). Với hình khối đơn giản và chiều cao thấp, đèn cũng có chức năng dẫn lối, giúp người lưu thông được an toàn và tạo hiệu ứng đẹp, thu hút tại các điểm. Ngoài ra, đèn có thể kết hợp với các loại bóng đèn led có màu sắc khác nhau càng làm tăng hiệu ứng cho đèn. Do đặc trưng của vật liệu chao đèn bằng kính nhựa trong màu vàng nhạt nên giúp giảm độ chói của đèn, tăng độ mờ ảo, đèn thích hợp cho những khu vực yên tĩnh, riêng tư của quán cà phê. Ánh sáng đèn chiếu lên nên có thể đặt đèn chiếu hướng vào các điểm nhấn trang trí trên cao như: tán cây, các bức tranh trang trí trên trần, các chi tiết trang trí trên cao. Đèn phù hợp với không gian tĩnh của các quán cà phê mang phong cách sân vườn nhiệt đới, vườn đồng quê Việt Nam.

\subsubsection{Mẫu đèn 2}

Với mục đích sử dụng những vật dụng, vật liệu quen thuộc để tạo mẫu đèn mới lạ nhưng gần gũi với cuộc sống, thiết kế sử dụng bộ ấm trà làm ý tưởng (Hình 10). Đèn có cấu tạo gồm 3 phần là dây treo bằng kim loại tạo sự chắc chắn và đảm bảo an toàn cho người sử dụng; bộ ấm và tách trà làm bằng đất nung, gốm sứ hoặc kim loại tùy theo yêu cầu của người sử dụng; bóng đèn Led diode màu vàng giúp liên tưởng đến dòng nước trà chảy ra tạo cảm giác lạ mắt và hứng thú cho thực khách, dây đèn còn giúp che dây treo tách trà. Áp dụng phương pháp chiếu xuống (down lighting) nguồn sáng đặt trên tầm mắt người cung cấp, ánh sáng dịu nhưng đủ cho các hoạt động thư giãn, trò chuyện, uống trà hay cà phê. Với dây treo thả, mẫu đèn 2 dễ sử dụng và phù hợp với nhiều không gian như giàn hoa, không gian nội thất (bàn, ghế), tiểu cảnh trang trí dưới đất (Hình 11). Đèn làm từ vật liệu gốm sứ hoặc kim loại nên phù hợp với đa dạng các quán cà phê mang phong 

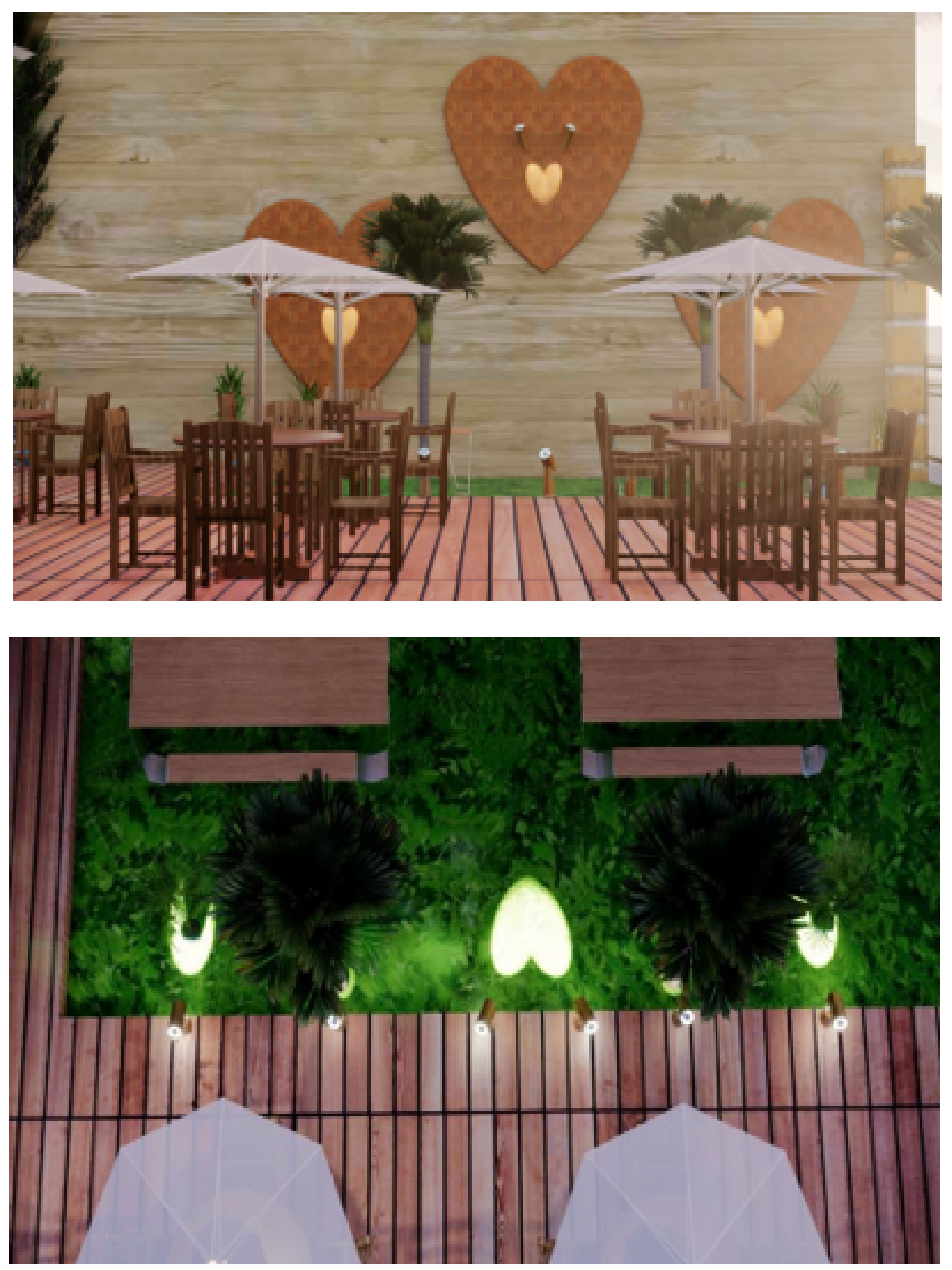

Hình 15. Phối cảnh mẫu đèn 4. 


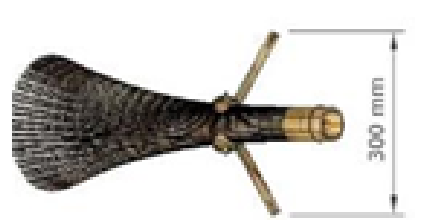

MĀT BÃNG CHI TIẾT DỀN

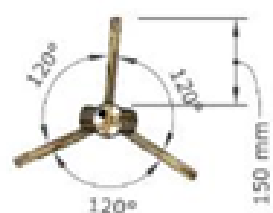

MĂT BÃNG CHI TIẾt TRU DEN

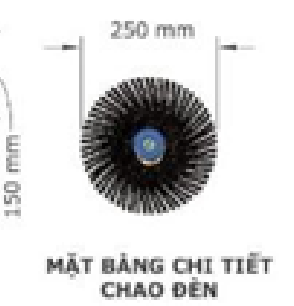
CHAO DÉN

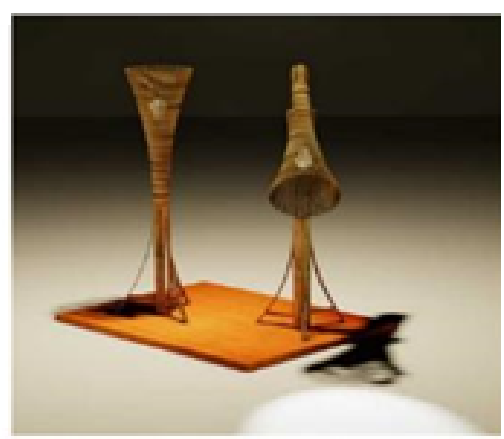

HìnH ẢNH MĀU oÈn

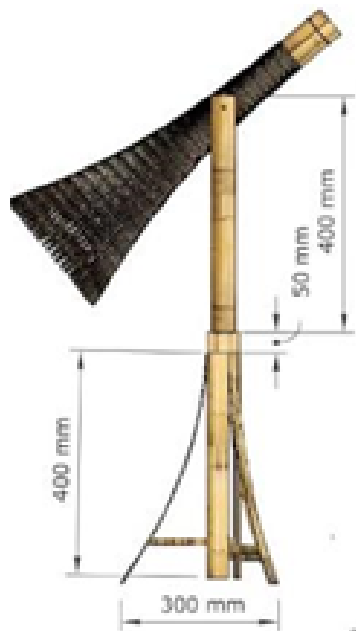

MĂT DÚNG CHI TIẾT อẺ

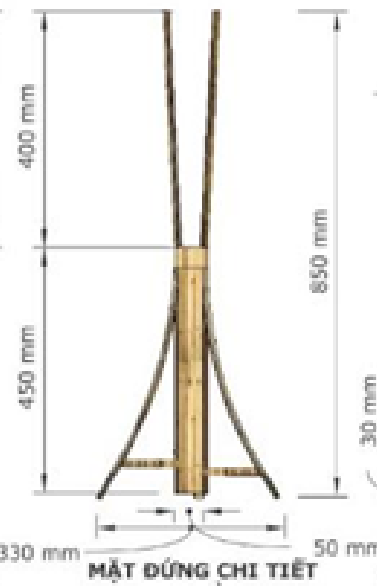

TRU DEN

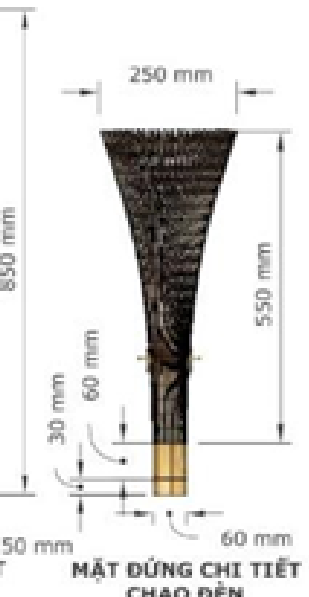

CHAO DĖN

Hình 16. Chi tiết mẫu đèn 5 .

cách từ hiện đại, phong cách Vintage, vườn thiền, đến vườn tổng hợp.

\subsubsection{Mẫu đèn 3}

Mặt nước là một trong năm yếu tố tạo hình của cảnh quan (Han, 1996). Ý tưởng dòng nước với các hạt nước được làm từ thủy tinh màu xanh nước biển kết hợp với sự sắp đặt vị trí của đèn tạo nên hiệu ứng nước từ dưới mặt hồ phun trào lên trên (Hình 12). Đèn có cấu tạo gồm 3 phần là đế đèn có kích thước $1.500 \mathrm{~mm}$ x 500 mm bằng nhựa tổng hợp giả đá granite tạo sự an toàn trong quá trình lắp đặt và vận hành, giảm chi phí thi công, cao 200 mm; 3 bóng đèn Led tròn âm tường đặt dưới phần đế đèn tạo nguồn sáng chính chiếu từ dưới lên trên; 84 bóng đèn hình giọt nước được bố trí vòng quanh đế đèn và thay đổi độ cao kiểu zizag. Ba bóng đèn Led chiếu thẳng đứng từ dưới lên kết hợp với bóng đèn thủy tinh chiếu sáng $360^{\circ}$ (up lighting for $360^{\circ}$ viewing) tạo điểm nhấn cho khu vực lắp đặt đèn. Ánh sáng chuyển tiếp giữa các bóng đèn vừa tạo cảm giác huyền ảo, nhẹ nhàng nhưng cũng không kém phần tinh tế. Đèn có thể bố trí tại khu vực hồ nước, các tiểu cảnh non bộ hoặc tiểu cảnh khô giả mặt hồ trong các quán cà phê mang phong cách sân vườn nhiệt đới, vườn hiện đại hay kết hợp (Hình 13).

\subsubsection{Mẫu đèn 4}

Thiết kế lấy hình tượng lũy tre mọc hai bên con đường làng làm ý tưởng cho mẫu đèn dẫn lối (Hình 14). Đèn có cấu tạo gồm 3 phần là chao đèn và trụ đèn sử dụng ống tre hình trụ, sơn chống thấm nước và chống mối mọt. Phía trên lắp đặt lớp kính nhựa thuỷ tinh trong suốt dày 2 $\mathrm{mm}$. Phần chao đèn và trụ đèn được kết nối với nhau bằng một khớp nối để có thể gập chao đèn lên xuống; bóng đèn Led, đui E27, công suất $4 \mathrm{~W}$ đường kính vỏ 50 mm, ánh sáng màu vàng; đế đèn cao $30 \mathrm{~mm}$ làm bằng vật liệu kim loại sơn chống rỉ sét màu giả tre. Với phần chao đèn có thể gập lên xuống một góc $180^{\circ}$ mẫu đèn này có thể kết hợp với nhau tạo thành nhiều phương pháp chiếu 


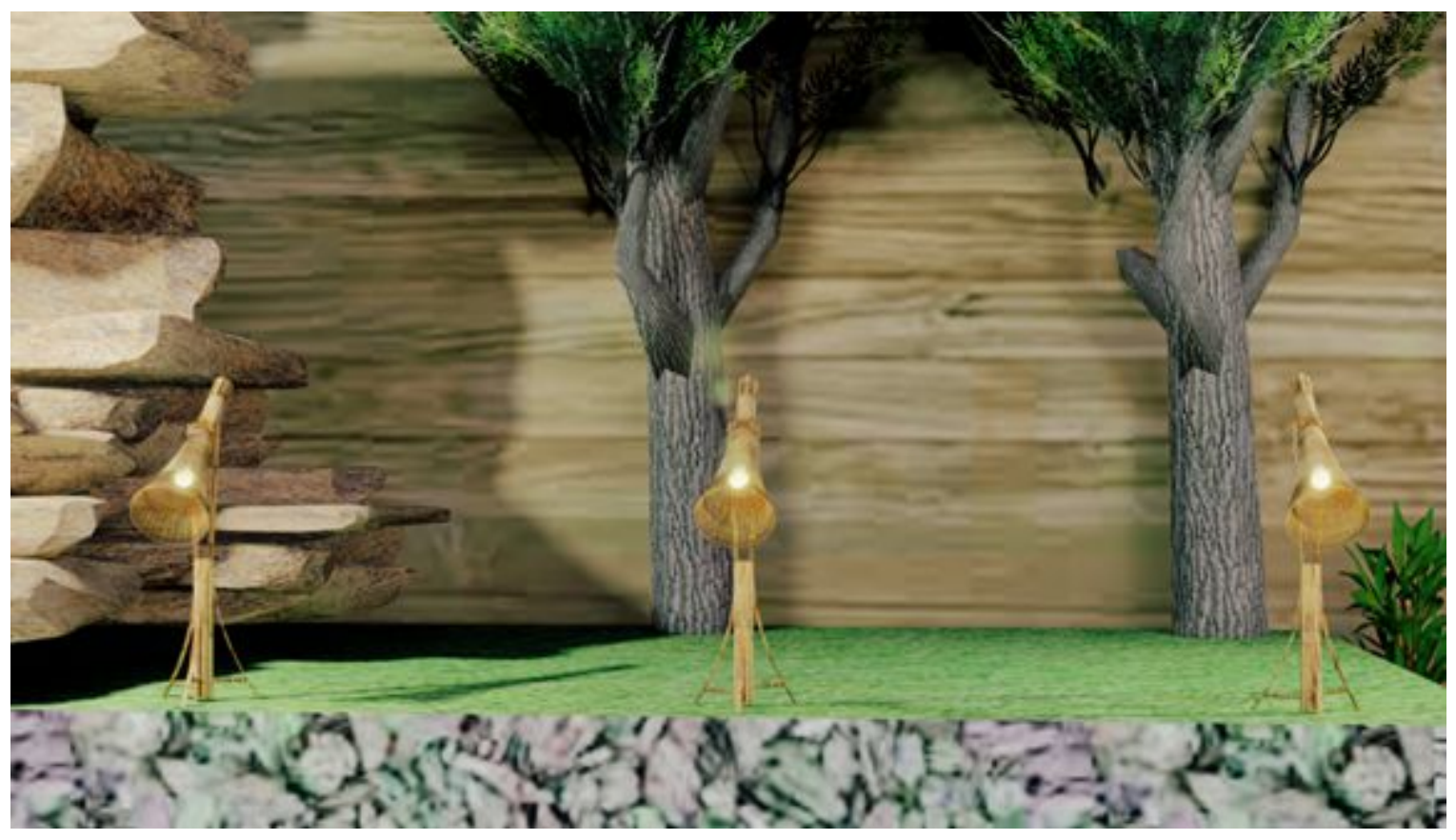

Hình 17. Phối cảnh mẫu đèn 5 .

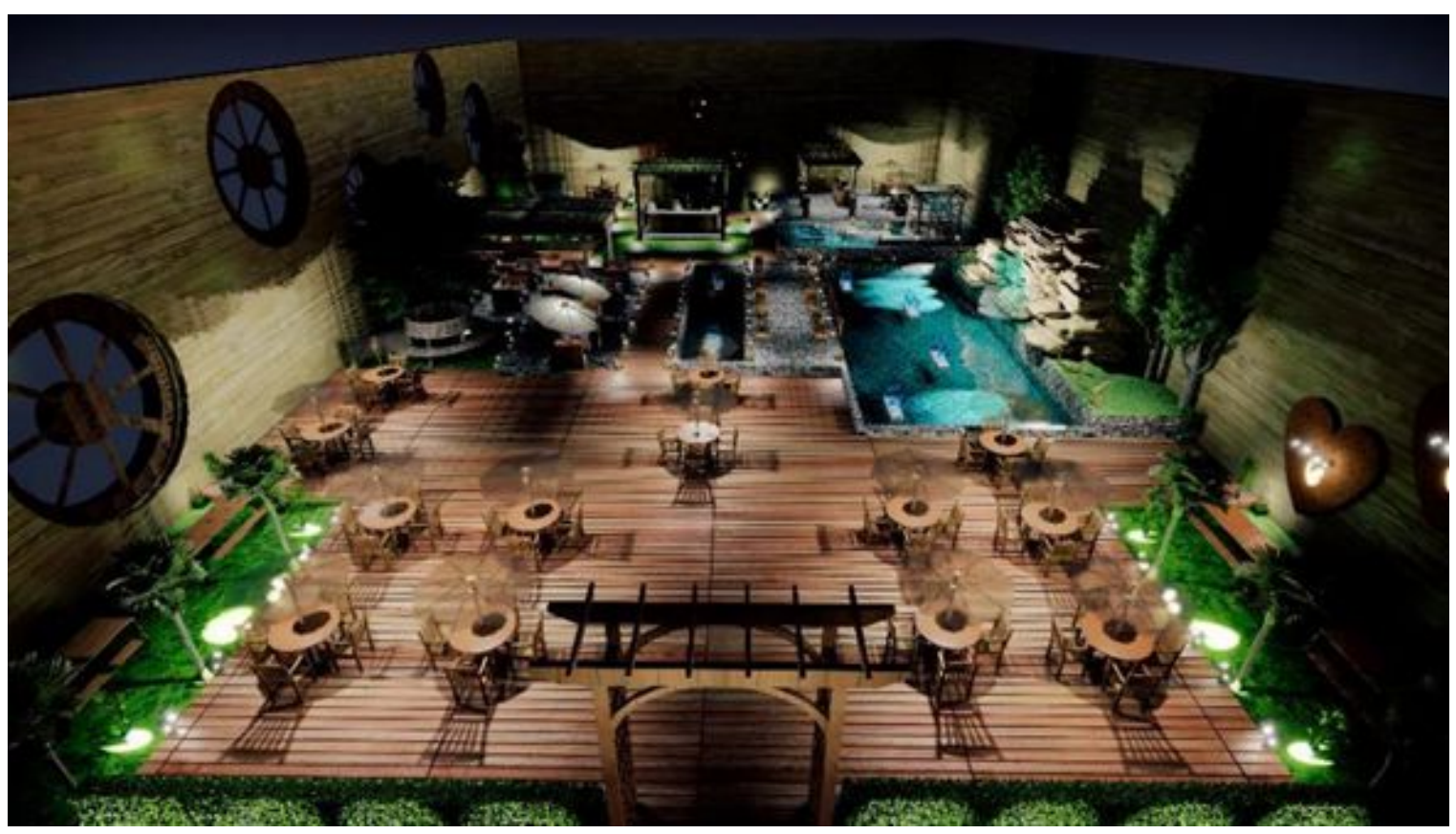

Hình 18. Sự kết hợp 5 mẫu đèn trong thiết kế.

sáng như chiếu sáng lên, chiếu sáng trực tiếp lối đi, chiếu sáng định hướng tùy theo vị trí lắp đặt đèn và góc chiếu của đèn. Mẫu có thể được đặt dọc lối đi hoặc kết hợp 2 đèn với nhau tạo hiệu ứng trái tim bố trí trên tường (Hình 15). Đèn phù hợp với các quán cà phê mang phong cách nhiệt 
đới, vườn làng quê Việt Nam, vườn kết hợp. Tùy vị trí lắp đặt và góc chiếu đèn có thể chiếu sáng tán cây, bụi hoa, các điểm nhấn, tiểu cảnh trang trí trong quán. Ánh sáng đèn màu trắng nên phù hợp với các khu vực yên tĩnh, thư giãn của quán.

\subsubsection{Mẫu đèn 5}

Nôm bắt cá là một vật dụng gần gũi với người Việt Nam. Vì nôm đã được trang trí cho một số quán cà phêe nên nhóm nghiên cứu cải tiến để mẫu đèn có thể thay đổi góc chiếu rộng gần $300^{\circ}$ tạo sự khác biệt (Hình 16).

Đèn có cấu tạo gồm 3 phần là trụ đèn có chiều cao $850 \mathrm{~mm}$ hình trụ làm bằng tre. Thân đèn có ba chân chống bố trí một góc $120^{\circ}$ giúp đèn đứng vững và phía trên có hai thanh tre cao dùng để cố định phần chao đèn; chao đèn hình chiếc nôm có đường kính $250 \mathrm{~mm}$, những nan tre được sắp xếp với khoảng cách vừa đủ để các tia sáng của đèn rọi qua giúp tạo hiệu hứng bóng đổ gây hứng thú cho người thưởng ngoạn; 1 bóng đèn Led màu trắng, đui E27. Với phần chao đèn có thể thay đổi góc chiếu rộng gần $300^{\circ}$ mẫu đèn 5 có thể áp dụng nhiều phương pháp chiếu như chiếu lên, chiếu rọi tùy theo vị trí lắp đặt và hướng chiếu của đèn (Hình 17). Đèn có thể lắp đặt cho đa dạng không gian như cổng, đường dạo, bậc thang, gần thác nước, dưới tán cây lớn hoặc kết hợp trong các tiểu cảnh. Vị trí lắp đèn rất đa dạng, có thể lắp dưới đất, trên tường và điều chỉnh hướng chiếu để dẫn lối đi hoặc các vị trí điểm nhấn, tiểu cảnh (Hình 18). Đèn được làm từ tre với hình dáng vừa truyền thống vừa hiện đại nên phù hợp với các quán cà phê mang phong cách sân vườn nhiệt đới, đồng quê, hiện đại hay kết hợp.

\section{Kết Luận và Kiến Nghị}

Nghiên cứu đã điều tra được 40 quán cà phê sân vườn ở quận Thủ Đức, TP. Hồ Chí Minh với các đặc tính của đèn trang trí như loại đèn, màu sắc ánh sáng, vị trí lắp đặt. Đề tài cũng thiết kế được 5 mẫu đèn với các ý tưởng từ thiên nhiên và dân gian. Đề tài chỉ dừng lại ở việc đề xuất thiết kế mà chưa tiến hành thi công và lắp đặt để theo dõi hiệu quả các loại đèn này. Để các mẫu đèn có thể áp dụng tại nhiều quán cà phê, cần có khảo sát quy mô lớn hơn về không gian và thời gian. Đồng thời, tiến hành thực nghiệm chiếu sáng để đánh giá hiệu quả chiếu sáng.

\section{Lời Cảm Ơn}

Nghiên cứu này được hỗ trợ kinh phí bởi Trường Đại học Nông Lâm TP. Hồ Chí Minh.

Cảm ơn nhóm hỗ trợ thu thập số liệu: Nguyễn Văn Quân, Trần Thị Chính, Ninh Thị Thu Hoài, Nguyễn Thị Bích Trâm, Đoàn Thị Kim Oanh, Hồ Thị Thanh Tâm, Trần Thị Tánh, Nguyễn Thị Tuyết Hương và Nguyễn Thị Bích Tuyền. Cảm ơn chuyên gia cơ điện Lê Minh Cường đã góp ý về kỹ thuật cho các mẫu thiết kế.

\section{Lời Cam Đoan}

Bài báo được sự đồng thuận của tất cả tác giả đứng tên.

\section{Tài Liệu Tham Khảo (References)}

Alison, J. X., \& Aparna, A. L. (2014). Incandescent affect: Turning on the hot emotional system with bright. Journal of Consumer Psychology 24(2), 207-216.

Beccali, M., Bonomolo, M., Leccese, F., Lista, D., \& Salvadori, G. (2018). On the impact of safety requirements, energy prices and investment costs in street lighting refurbishment design. Energy 165(B), 739-759.

Blight (TCL Solight Co., LTD). (2019). The art of LED lights decorating coffee shop. Retrieved June 7, 2020, from https://blight.com.vn/nghe-thuat-den-led-trangtri-quan-coffee/.

Boyce, P. R. (2019). The benefits of light at night. Building and Environment 151, 356-357.

Duijnhoven, J. V., Aarts, M. P. J., Kort, H. S. M., \& Rosemann, A. L. P. (2018). External validations of a non-obtrusive practical method to measure personal lighting conditions in offices. Building and Environment 134, 74-86.

Han, N. T. (1996). Landscape architecture. Ha Noi, Vietnam: Construction Publishing House.

Harris, W. C., \& Dines, T. N. (1998). Time-saver standards for landscape architecture. New York, USA: McGraw-Hill.

Juchem, J., Lefebvre, S., Mac, T. T., \& Ionescu, C. M. (2018). An analysis of dynamic lighting control in landscape offices. IFAC Papers OnLine 51(4), 232-237.

LDA (Landscape design advisor). (2013). Landscape lighting design techniques for creating dramatic effects. Landscape design advisor. Retrieved April 2, 2020, from http://www.landscape-designadvisor.com/ideas-tips/landscape-lighting/lightingtechniques.

Nguyen, H. T. (2019). Some opinions and principles about artistic lighting of high-rise architecture buildings in urban areas. Architecture Magazine August-2019. Retrieved March 11, 2020 , 
from https://www.tapchikientruc.com.vn/chuyenmuc/mot-so-quan-diem-va-nguyen-tac-ve-chieu-sangnghe-thuat-mat-ngoai-kien-truc-nha-cao-tang-trongdo-thi.html.

Nguyen, N. (2019). Coffee in Vietnamese life. Travellive news. Retrieved April 2, 2020, from https://vntravellive.com/ca-phe-trong-doi-songnguoi-viet-d28955.html.

Nhung, P. (2015). Light and emotion. Information Science and Technology (STINFO) 11, 26-27.
Tran, V. D., Nguyen, T. H, Nguyen, T. B. L, Nguyen, T. H., Nguyen, T. S, Hong, Q. T., \& Nguyen, T. T. (2017). Several factors of lighting conditions affect the vision of workers manufacturing electronic components and applying eye relaxation solutions. Vietnam General Confederation of Labor. Retrieved November 11, 2019, from http://vnniosh.vn/chitiet_NCKH/id/7392/Mot-soyeu-to-dieu-kien-chieu-sang-anh-huong-den-thi-giaccua-cong-nhan-san-xuat-linh-kien-dien-tu-va-ap-dunggiai-phap-thu-gian-mat. 